\title{
COMPARATIVE ANATOMICAL AND MORPHOLOGICAL STUDIES OF THE EPIDERMAL AND CORTICAL PARENCHYMA HYPOCOTYL CELLS OF TWO TOMATO GENOTYPES (Solanum lycopersicum L.) UNDER SODIUM CHLORIDE STRESS in vitro
}

\author{
L.R. BOGOUTDINOVA1, 2 , G.B. BARANOVA ${ }^{1}$, E.N. BARANOVA', \\ M.R. KHALILUEV1, 2
}

\author{
${ }^{1}$ All-Russian Research Institute of Agricultural Biotechnology, Federal Agency of Scientific Organizations, 42, ul. \\ Timiryazevskaya, Moscow, 127550 Russia, e-mail marat131084@rambler.ru; \\ ${ }^{2}$ K.A. Timiryazev Russian State Agrarian University-Moscow Agrarian Academy, 49, ul. Timiryazevskaya, Moscow, \\ 127550 Russia \\ Acknowledgements: \\ Supported by Russian Foundation for Basic Research, project № 16-34-01331 (mol_a)
}

Received January 9, 2016

\section{Abstract}

Improving plant resistance to unfavorable environmental factors is one of the important tasks of modern agricultural production. The cultivated tomato is highly sensitive to salinity. Understanding the physiological, biochemical, molecular and genetic adaptive mechanisms of tomato resistance to salinity as a complex trait is an essential part of most fundamental studies, the results of which are increasingly finding practical application during the last decade. However, the data on the effect of sodium chloride on cell organization of different tomato tissues and organs are scarce. Thus, the purpose of the study was to investigate cell organization of the epidermis and parenchyma cortical tissues of tomato hypocotyl (Solanum lycopersicum L. line YaLF and cultivar Rekordsmen) under chloride salinity in vitro. Fragments of 10-12-day-old aseptically germinated tomato seedlings, whose roots have been removed, were transferred on root induction medium $(1 / 2$ MS, $2 \%$ sucrose, $0.2 \mathrm{mg} / 1$ indole-3-butyric acid) supplemented with $0-250 \mathrm{mM} \mathrm{NaCl}$. After 8 days in culture, middle part of hypocotyls were excised from rooted seedlings and prepared for light microscopy. Histological examination revealed significant differences between genotypes in shape and average cross-sectional areas of the epidermal and cortical parenchyma cells of hypocotyl. The addition of $\mathrm{Na}+$ and $\mathrm{Cl}^{-}$ions to culture medium significantly affected the size of the intercellular spaces in the cortical parenchyma as well as the average cross-sectional areas and shape epidermal and cortical parenchyma hypocotyl cells of both tomato genotypes. The average cross-sectional areas of epidermal and cortical parenchyma hypocotyl cells of tomato line YaLF under $50 \mathrm{mM} \mathrm{NaCl}$ were significantly less (1.2 and 1.6 times, respectively) compared with control conditions (medium without $\mathrm{NaCl}$ ). Epidermal and cortical parenchyma hypocotyl cells of tomato cultivar Rekordsmen decreased in size at higher concentrations of $\mathrm{NaCl}$ in the culture medium (100 and $150 \mathrm{mM} \mathrm{NaCl}$, respectively). Dramatic increase in the cells areas of both tissue types of tomato line YaLF were observed under $250 \mathrm{mM} \mathrm{NaCl}$ salinity. In addition, under high salinity treatments there was a considerable change in the shape of epidermal (cells obtained angular contours) and cortical parenchyma hypocotyl cells (cell flattening) of line YaLF. Unlike line YaLF, the cross-sectional areas of epidermal and cortical parenchyma hypocotyl cells of tomato cultivar Rekordsmen was no significant differences between 0 and $250 \mathrm{mM} \mathrm{NaCl}$ treatment. The dramatic difference between the two tomato genotypes was observed by a change in the cross-sectional areas of intercellular spaces in cortical parenchyma hypocotyl cells under salt treatments. Epidermal and cortical parenchyma cells of tomato hypocotyls cultivar Rekordsmen were less sensitive to the presence of $\mathrm{NaCl}$ in the culture medium, compared with the line YaLF. The revealed changes in shape and size of epidermal and cortical parenchyma hypocotyl cells can be used as cytological markers for comparative evaluation of tomato genotypes in sensitivity and/or resistance to salinity.

Keywords: tomato, Solanum lycopersicum L., salt stress, hypocotyl anatomy, in vitro culture

Salinity, one of the main abiotic stressors, restricts cultivation of most crops in many agro-climatic areas, and significantly decreases crop production [1]. In the word an area of 950,000,000 hectares, according to FAO, is salinized, including alkaline salinity. In different reports, from 33 to $50 \%$ of total irrigated 
agriculture areas are subjected to salinization [2, 3]. Tomato (Solanum lycopersicum L.) is high sensitive to salinity with the soil electrical conductivity $\left(\mathrm{EC}_{\mathrm{e}}\right)$ threshold of $2.5 \mathrm{dS} / \mathrm{m}$ [4], that corresponds to low saline soils as to the FAO classification $\left(\mathrm{EC}_{\mathrm{e}}=2.0-4.0 \mathrm{dS} / \mathrm{m}\right)$.

A prerequisite for studying mechanisms of plant resistance to abiotic stress, in particular to salinity, is controlled conditions. This is quite difficult to achieve when testing in pots in greenhouses or even impossible for field tests. Changing environmental factors (temperature, relative humidity, light intensity, air pollution, etc.) radically affect plant response to salinity, leading either to its strengthening, or to compensation of the visible manifestations $[5,6]$. Techniques based on adding toxic ions to media for plant cultivation or tissue cultures allow for a relatively rapid screening for potential tolerance in the early development stages which in many crops, including a tomato, are the most crucial $[2,6]$. Noteworthy, in some experiments, a direct correlation have been found between the salinity tolerance in callus tissue in vitro and in adult plants in. This trend was traced in cultivated and wild tomato species [7, 8], and in Cucurbitaceae plants (melon, watermelon, cucumber) [9].

Different morphometric growth parameters of tomato seedlings and regenerants are suppressed in vitro by salinity, together with a notable decrease in leaf chlorophyll content occurred [6, 8]. High sodium chloride or sodium sulfated levels affect respiration, water balance and mineral nutrition [10-12]. These are due to hyperosmotic and toxic effects of excess ion concentrations [13, 14].

For last decades, the researchers are mostly focused on mapping QTLs for abiotic stress tolerance which is polygenic in nature in tomato plants. This approach is practically used in marker-assisted selection in tomato breeding for salinity tolerance $[15,16]$. Significant progress in understanding salt tolerance was achieved due to genetic engineering technology, i.e. by introduction of heterologous genes into plant genome. Using different strategies, numerous data are obtained about transgenic tomato plants tolerant to salinity in vitro, under hydroponic technology and when growing in greenhouses [2, 5, 17]. However, the tissue mesostructures in different tomato organs as influenced by toxic ions still remain poor known [18-20]. Studying mesostructure, together with molecular, genetic, biochemical and physiological mechanisms, will contribute to better understanding stress adaptation and salt tolerance in plants, allowing for development of the diagnostic tests and, ultimately, the improved breeding technologies.

This study has, for the first time, compared the anatomical and morphological parameters of epidermal and parenchymal hypocotyl cells as influenced by $\mathrm{Na}^{+}$and $\mathrm{Cl}^{-}$concentrations in vitro using an experimental model of two tomato genotypes different in salt tolerance.

Our aim was to investigate cell mesostructure in epidermis and cortical parenchyma of tomato hypocotyls at $\mathrm{NaCl}$ salinization.

Technique. Aseptic tomato (Solanum lycopersicum L.) seedlings of more salt-sensitive line YaLF, the male parent for the $F_{1}$ Yunior hybrid, and more salt-tolerant variety Rekordsmen were used. To grow aseptic seedlings, the seeds were $96 \%$ ethanol-sterilized for $10 \mathrm{sec}$ and then exposed to $20 \%$ ACE chlorine commercial bleach with few Tween 20 drops (Merck, Germany) for 7-8 min. The threated seeds were 3-4 times rinsed with distilled water and placed on Murashige-Skoog (MS) agar (0.7 \%) [21], supplemented with $3 \%$ sucrose. At 1st true leaf the roots were cut off, and the upper fragments, 1.5$2.0 \mathrm{~cm}$ in length, were placed on $1 / 2$ MS agar $(0.7 \%)$ supplemented with $2 \%$ sucrose and $0.2 \mathrm{mg} / 1$ indole-3-butyric acid (3-IBA) for rhizogenic induction. The effect of $50,100,150,200$ and $250 \mathrm{mM} \mathrm{NaCl}$ in the media was tested vs no $\mathrm{NaCl}$ added in the control. Plants were grown at controlled temperature $\left(23{ }^{\circ} \mathrm{C}\right)$ 
and light conditions (3.0 klx, 16/8 h for day/night).

On day 8 , the 2-3 mm hypocotyl fragments were excised from the middle part of rooted seedlings, fixed with $2.5 \%$ glutaraldehyde (Merck, Germany) in $0.1 \mathrm{M}$ phosphate buffer ( $\mathrm{pH} 7.2$ ) with $1.5 \%$ sucrose. Posfixation in $1 \% \mathrm{OsO}_{4}$ (Sigma, USA), dehydration through ascending series of ethanol (30, 50, 70, 96 and $100 \%$ ), propylene oxide treatment (Fluka, Germany), and epoxy embedding in Epon ${ }^{\mathrm{TM}} 812$ and Araldite (Merck, Germany) were conventional [22]. An ultra-microtome LKB-V (LKB, Sweden) was used for sectioning. An Olympus BX51 microscope (Olympus, Japan) with a Color View II camera (Soft Imaging System, Germany) were used for viewing 1-2 $\mu$ m-thick sections and recording digital images. Cell-A software (Olympus, Japan) was applied to calculate cross-sectional areas for epidermal and cortical parenchyma hypocotyl cells, and intercellular space. At least 500 cells of each tissue from three different seedlings, or 20-30 sections, were analyzed.

Data were processed using parametric Student's test, Fisher's test and Duncan's test.

Results. The plant cells first respond to an excess of $\mathrm{Na}^{+}$and $\mathrm{Cl}^{-}$by water and osmotic homeostasis regulation through modifying different physiological functions. This results from the coordinated processes in the cytoplasm and the cell wall leading to changes in cell size and shape [13, 23].

We have revealed significant differences on the size and shape of epidermal hypocotyl cells between studied tomato genotypes diverse in salt tolerance when growing without adding $\mathrm{NaCl}$. The epidermal cell area in the YaLF line was 1.3 -fold as much as in the Rekordsmen variety $\left(843.5\right.$ and $644.5 \mu \mathrm{m}^{2}$, respectively) (Fig. 1, A). Besides, in the YaLF line the epidermal cells were more rounded in shape (Fig. 2, A). The same we observed in the parenchymal hypocotyl cells which were rounded in the YaLF line (see Fig. 2, A) and irregular in shape in the Rekordsmen variety (see Fig. 2, G). Moreover, the parenchymal cell area in the YaLF line was also larger compared to the Rekordsmen variety (see Fig. 1, B).

A

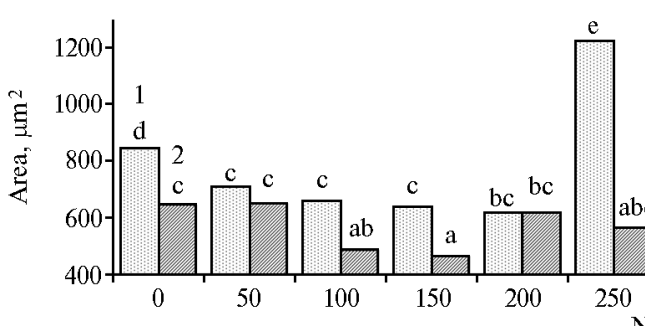

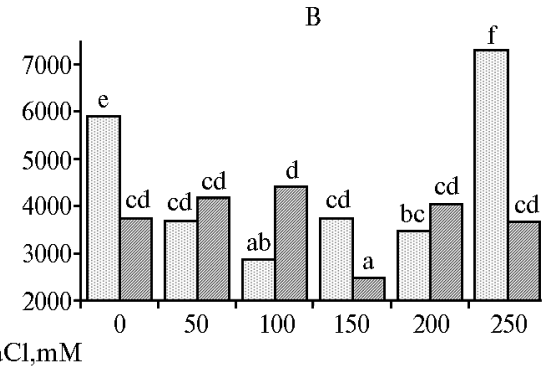

Fig. 1. Areas of epidermal (A) and core parenchymal cells (B) in hypocotyls of tomato (Solanum lycopersicum L.) seedlings grown in vitro on Murashige-Skoog agar at different $\mathrm{NaCl}$ concentrations: 1 - YaLF line (less salt-tolerant), 2 - variety Rekordsmen (more salt-tolerant). Differences between the variants marked with the same letters are insignificant according to Duncan's criterion $(\alpha=0.05)$.

Also we have found the differences between hypocotyl cell size and shape depending on $\mathrm{NaCl}$ concentrations, tissue specificity and plant genotypes (see Fig. 1, 2). In case of the least studied $\mathrm{NaCl}$ concentration $(50 \mathrm{MM})$ the epidermal cell area in YaLF line was substantially less when compared to control. At 100 to $200 \mathrm{mM} \mathrm{NaCl}$ the cell size remained unchanged but at $250 \mathrm{mM} \mathrm{NaCl}$ it increased significantly and exceeded that at 0 to $200 \mathrm{MM} \mathrm{NaCl}$. Besides, at $250 \mathrm{mM} \mathrm{NaCl}$ the epidermal cell became angular in contours (se Fig. 2, F).

Unlike YaLF, in Rekorsmen variety the epidermal cell area in hypocotyls significantly decreased at $100 \mathrm{mM}$, whereas at 200 and $250 \mathrm{MM} \mathrm{NaCl}$ it in- 
creased to that in control. At moderate and strong salinity the hypocotyl epidermal cells in Rekordsmen variety became ovate-oblong, i.e. more tissue-specific in shape (see Fig. 2, I-L).
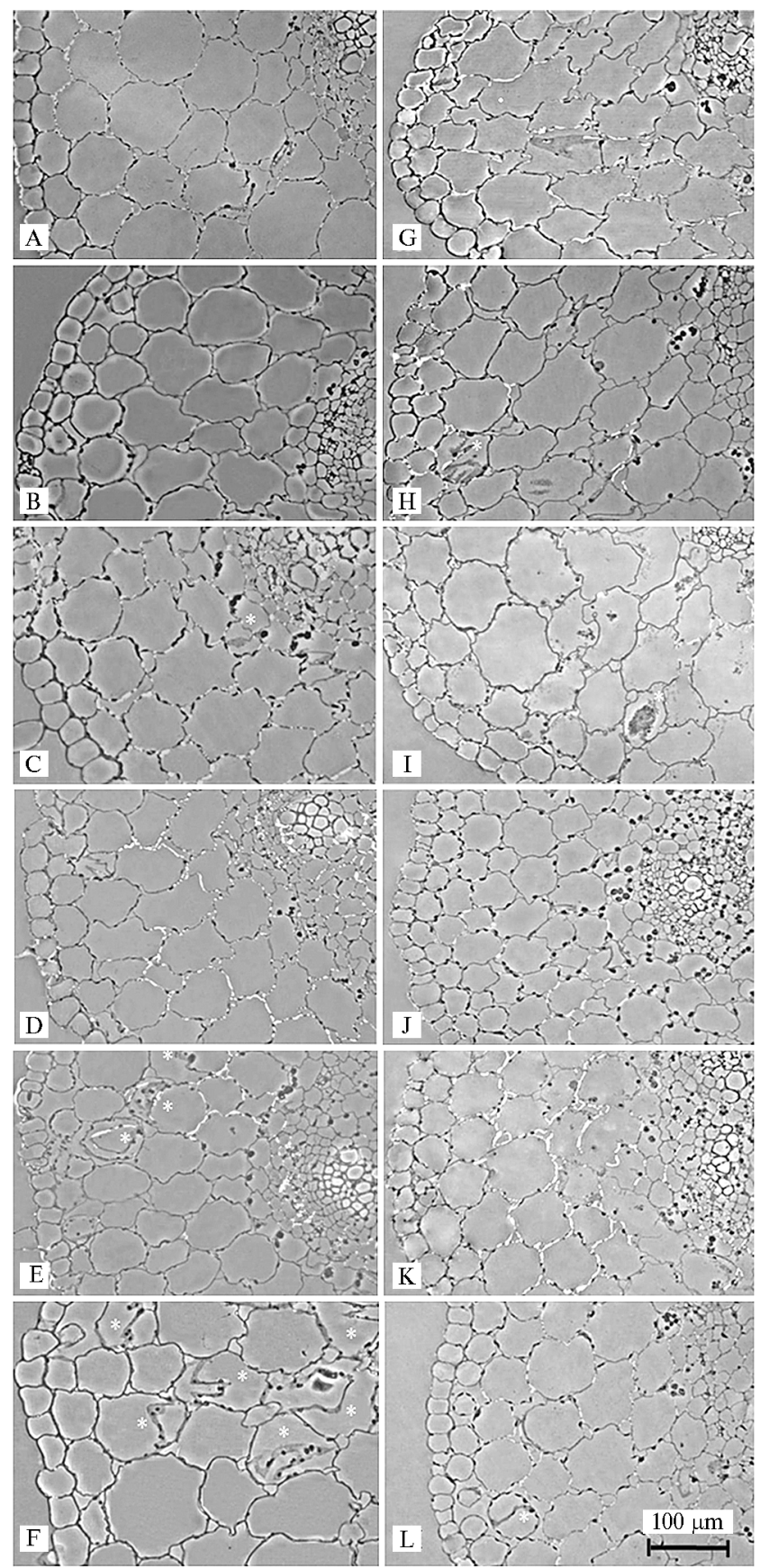

Fig. 2. Cross sections of middle part of hypocotyls in tomato (Solanum lycopersicum L.) seedlings of line YaLF (A-F, less salt-tolerant) and Rekordsmen variety (G-L, more salt-tolerant) grown in vitro on Murashige-Skoog agar at different $\mathrm{NaCl}$ concentrations: $\mathrm{A}, \mathrm{G}-$ control without $\mathrm{NaCl} ; \mathrm{B}$, $\mathrm{H}-50 \mathrm{mM} \mathrm{NaCl}$; C, I - $100 \mathrm{mM} \mathrm{NaCl}$; D, J - $150 \mathrm{mM} \mathrm{NaCl}$; E, K - $200 \mathrm{mM} \mathrm{NaCl}$; F, L $250 \mathrm{mM} \mathrm{NaCl}$. Asterisks mark plasmolysed parenchymal cells of the hypocotyl cortex.

In the parenchymal cells, also sensitive to salinization, the reaction to $\mathrm{NaCl}$ differed between genotypes depending on salt concentration (see Fig. 1, B). At 50 and $100 \mathrm{mM} \mathrm{NaCl}$ cell area decreased in the line YaLF. Moreover, 
the parenchymal cells became strongly flattened in shape (see Fig. 2, D-F). At $250 \mathrm{mM} \mathrm{NaCl}$ the parenchymal cell area in the YaLF seedlings increased 1.2 times compared to control, and 2.0-2.5 times compared to other $\mathrm{NaCl}$ levels tested.

At 50 and $100 \mathrm{mM} \mathrm{NaCl}$ the area of the hypocotyl parenchymal cells in the Rekordsmen variety, unlike YaLF line, did not decrease compared with the control. In contrast, an increase was observed (4158 and $4412 \mathrm{~mm}^{2}$ at 50 and $100 \mathrm{mM} \mathrm{NaCl}$, respectively), though we did not found statistically significant differences when compared these two variants to each other and to control. Smaller area of parenchymal cells was observed in the Rekordsmen variety at $150 \mathrm{mM} \mathrm{NaCl}$. Noteworthy, in this variety the high levels of toxic ions influenced parenchymal cell configuration. Like epidermal cells, they possessed rounded shape, more characteristic of this tissue (see Fig. 2, J-L).

Reducing the epidermal cell area in both genotypes and cortical parenchyma cell area in line YaLF, together with a change in their shape under moderate salinity can be treated in several ways. On the one hand, it can be positive cells adaptive response to stress. It is known that the water balance disorder due to $\mathrm{NaCl}$, which is expressed in the reduction of water content of tissues, results in a reduction in cell size and thus lowers the osmotic potential of the cell sap $[24,25]$. On the other hand, the decrease in the cell size can be due to inhibition of their growth by stretching because of the cytoskeleton destruction. C. Wang et all. (26) showed that $12 \mathrm{hr}$ exposition to $150 \mathrm{mM}$ and $250 \mathrm{mM} \mathrm{NaCl}$ led to an increase in polymeric actin level and filament bundle diameter in root, hypocotyl and cotyledons epidermal cells of Arabidopsis thaliana (L.) Heynh. seedlings. After $18 \mathrm{hr}$ at $150 \mathrm{mM} \mathrm{NaCl}$ the actin cytoskeleton was still not destructed while $250 \mathrm{mM} \mathrm{NaCl}$ caused destruction of actin filaments followed by seedling death.

The sharp increase in the hypocotyl parenchymal and epidermal cell area, when culturing seedlings of YaLF line at $250 \mathrm{mM} \mathrm{NaCl}$, may be related to their death. Indeed, necrosis occurred in hypocotyl part which contacts directly with the nutrient medium. In these seedlings roots did not regenerate. Besides (see Fig. 2, F), we clearly observed a large number of parenchymal cells with the signs of irreversible plasmolysis, which apparently led to their death and subsequent swelling of the dead cells. However, this assumption should be additionally proved by electron microscopy and histochemical methods.

The presence of toxic $\mathrm{Na}^{+}$and $\mathrm{Cl}^{-}$ions induced changes of the intercellular spaces of the cortical parenchyma in the hypocotyl. At that, the genotypedependent responce was radically (Table).

Intercellular space $\left(\mu \mathrm{m}^{2}\right)$ in cortical parenchyma of hypocotyl in studies tomato (Solanum lycopersicum L.) genotypes in vitro as influenced by $\mathrm{NaCl}$

\begin{tabular}{l|cc}
\hline \multicolumn{1}{c|}{$\mathrm{NaCl}, \mathrm{mM}$} & $\begin{array}{c}\text { Line YaLF } \\
\text { (less salt resistant) }\end{array}$ & $\begin{array}{c}\text { Variety Rekordsmen } \\
\text { (more salt resistant) }\end{array}$ \\
\hline 0 & $108.8^{\mathrm{g}}$ & $92.1^{\mathrm{defg}}$ \\
50 & $82.1^{\mathrm{bcd}}$ & $128.2^{\mathrm{h}}$ \\
100 & $66.8^{\mathrm{ab}}$ & $93.4^{\mathrm{fg}}$ \\
150 & $77.4^{\mathrm{abcd}}$ & $94.9^{\mathrm{defg}}$ \\
200 & $87.7^{\mathrm{cdef}}$ & $67.2^{\mathrm{ab}}$ \\
250 & $100.3^{\mathrm{efg}}$ & $61.5^{\mathrm{ab}}$ \\
N o t e. Differences between the variants marked with the same letters are insignificant according to Duncan's cri- \\
terion $(\alpha=0.05)$
\end{tabular}

At $50 \mathrm{mM} \mathrm{NaCl}$ the intercellular space in variety Rekordsmen notable increased compared to control. The same was earlier found in mesophyll of true leaf in the seedlings of varieties Mariela and Cambell 28 at soil salinity (75 и $150 \mathrm{mM} \mathrm{NaCl}$ ) [19]. Increasing $\mathrm{NaCl}$ concentration resulted in a decrease in in- 
tercellular space in the variety Rekordsmen. Thus, at 100 and $150 \mathrm{mM} \mathrm{NaCl}$ it was comparable to the control, whereas at higher $\mathrm{NaCl}$ concentrations it was 1.4 and 1.5 times less, respectively.

Unlike variety Rekordsmen, intercellular space in hypocotyl cortex parenchyma of YaLF tomato seedlings at 50 to $200 \mathrm{mM} \mathrm{NaCl}$ was significantly lower compared with the control. The highest studied level of the stress agent resulted in an increase in intercellular space to that comparable with the control.

Thus, our experimental data are in line with previous evidences that in various tissues the cell reaction to chloride salinity not only varies significantly between species but also highly depends on genotype specificity within the same species.

So, the histological examination showed significant differences between the studied genotypes of tomato on the size and shape of the epidermal and parenchymal cells in hypocotyl cortex. In both genotypes toxic $\mathrm{Na}^{+}$and $\mathrm{Cl}^{-}$ ions affect significantly these cytomorphological parameters. Moreover, at salinity these genotypes differed on intercellular space of the cortex parenchyma in hypocotyl. IT was found out that sensitivity of epidermal and parenchymal cells to $\mathrm{NaCl}$ in tomato variety Rekordsmen was lower compared to line YaLF. Changing the size and shape of these types of tissue cells under $\mathrm{NaCl}$ salinization in vitro can be used as cytological markers for comparative evaluation for sensitivity or resistance to salt stress in tomato plants. To obtain the most objective and reliable results the comparative assessment must be carried out using a wide range of stress agent concentrations and anatomical and morphological parameters (both size and shape of cells).

\section{REFERENCES}

1. B o y e r J.S. Plant productivity and environment. Science, 1982, 218: 443-448 (doi: 10.1126/science.218.4571.443).

2. Foolad M.R. Recent advances in genetics of salt tolerance in tomato. Plant Cell Tiss. Org. Cult., 2004, 76(2): 101-119 (doi: 10.1023/B:TICU.0000007308.47608.88).

3. Flowe rs T.J. Improving crop salt tolerance. J. Exp. Bot., 2004, 55(396): 307-319 (doi: 10.1093/jxb/erh003).

4. Chinnusamy V., Jage ndorf A., Zhu J.-K. Understanding and improving salt tolerance in plants. Crop Sci., 2005, 45(2): 437-448 (doi: 10.2135/cropsci2005.0437).

5. Cuartero J., B o lari n M.C., A s in s M.J. Mo re no V. Increasing salt tolerance in the tomato. J. Exp. Bot., 2006, 57(5): 1045-1058 (doi: 10.1093/jxb/erj102).

6. Shibli R.A., Kushad M., Yous ef G.G., Li l a M.A. Physiological and biochemical responses of tomato microshoots to induced salinity stress with associated ethylene accumulation. Plant Growth Regulation, 2007, 51(2): 159-169 (doi: 10.1007/s10725-006-9158-7).

7. Perez-Alfoce a F., Estañ M.T., Caro M., B olarín M.C. Responses of tomato cultivars to salinity. Plant and Soil, 1993, 150(2): 203-211 (doi: 10.1007/BF00013017).

8. Cano E.A., Perez-Alfocea F., Moreno V., Caro M., B olarín M.C. Evaluation of salt tolerance in cultivated and wild tomato species through in vitro shoot apex culture. Plant Cell Tiss. Org. Cult., 1998, 53(1): 19-26 (doi: 10.1023/A:1006017001146).

9. $\mathrm{B}$ a ragé M. Identificación de fuentes de tolerancia a la salinidad y al estrés hídrico en especies silvestres de la familia Cucurbitaceae. PhD thesis. Universidad Politęcnica de Valencia, 2002.

10. B a ranova E.N., A kanov E.N., Gulevich A.A., Kurenina L.V., Danilov a S.A., K h a li lu e v M.R. Doklady RASKHN, 2013, 6: 13-16 (in Russ.).

11. Romero-Aranda R., Soria T., Cuartero S. Tomato plant-water uptake and plantwater relationships under saline growth conditions. Plant Sci., 2001, 160(2): 265-272 (doi: 10.1016/S0168-9452(00)00388-5).

12. Yadav S., I rfan M., A h mad A., Hay at S. Causes of salinity and plant manifestations to salt stress: a review. J. Environ. Biol., 2011, 32(5): 667-685.

13. Munns R., Teste r M. Mechanisms of salinity tolerance. Annu. Rev. Plant Biol., 2008, 59: 651-681 (doi: 10.1146/annurev.arplant.59.032607.092911).

14. B a r a n o va E.N., G u l e vi c h A.A. Sel'skokhozyaistvennaya Biologiya [Agricultural Biology], 2006, 1: 39-56 (in Russ.).

15. Fo olad M.R. Genome mapping and molecular breeding of tomato. Int. J. Plant Genomics, 
2007: 64358 (doi: 10.1155/2007/64358).

16. Monforte A.J., Asíns M.J., Carbone 11 E.A. Salt tolerance in Lycopersicon species. IV. Efficiency of marker-assisted selection for salt tolerance improvement. Theor. Appl. Genet., 1996, 93(5): 765-772 (doi: 10.1007/BF00224074).

17. Bhat nagar-M athur M., Vadez Z., Sharma K.K. Transgenic approaches for abiotic stress tolerance in plants: retrospect and prospects. Plant Cell Rep., 2008, 27(3): 411-424 (doi: 10.1007/s00299-007-0474-9).

18. Al-Tarde h S., Iraki N. Morphological and anatomical responses of two Palestinian tomato (Solanum lycopersicon L.) cultivars to salinity during seed germination and early growth stages. Afr. J. Biotechnol., 2013, 12(30): 4788-4797 (doi: 10.5897/AJB12.2707).

19. S a m O., Ramírez C., Co ronado M.J., Testilla no P.S., Risueño M.C. Changes in tomato leaves induced by $\mathrm{NaCl}$ stress: leaf organization and cell ultrastructure. Biologia Plantarum, 2004, 47(3): 361-366 (doi: 10.1023/B:BIOP.0000023878.58899.88).

20. Strogonov B.P., Kabanov V.V., S hevyakova N.I., Lapina L.P., Komizerko E.I., Popov B.A., Dostanova R.Kh., Prikhod'ko L.S., Kursan o v A.L. Struktura i funktsii kletok rastenii pri zasolenii [Plant cell structure and functions under salinity]. Moscow, 1970 (in Russ.).

21. Murashige T., S k o og F. A revised medium for rapid growth and bioassays with tobacco tissue culture. Physiologia Plantarum, 1962, 15: 473-497 (doi: 10.1111/j.1399-3054.1962.tb08052.x).

22. U ikli B. Elektronnaya mikroskopiya dlya nachinayushchikh [Electron microscopy for beginners]. Moscow, 1975 (in Russ.).

23. G o r s h k o va T.A. Rastitel'naya kletochnaya stenka kak dinamichnaya sistema [Plant cell wall as a dynamic system]. Moscow, 2007 (in Russ.).

24. Ku d o y a rova G.R., K h o lo d o v a V.P., V e s e lov D.S. Fiziologiya rastenii, 2013, 60(2): 155-165 (doi: 10.7868/S0015330313020140) (in Russ.).

25. Kholodova V.P., Meshcheryakov A.B., Aleksandrova S.N., Kuznet s o v Vl.V. Vestnik Nizhegorodskogo gosudarstvennogo universiteta im. N.I. Lobachevskogo. Seriya biologiya, 2001, 1: 151-154 (in Russ.).

26. Wang C., Zhang L., Yuan M., Ge Y., Li u Y., Fan J., Ruan Y., Cui Z., Tong S., $\mathrm{Zh}$ a ng S. The microfilament cytoskeleton plays a vital role in salt and osmotic stress tolerance in Arabidopsis. Plant Biology, 2010, 12: 70-98 (doi: 10.1111/j.1438-8677.2009.00201.x). 